\title{
Continuous Modeling for Design,Construction and Monitoring: A Case Study
}

\author{
Brian E. Bishop and Ronald B. Scheckenberger
}

This chapter explores, by way of a case study, the fundamental connection between theoretical modeling and practical design, construction, and monitoring of an engineered solution to a problem. The modeling associated with this design forms Chapter 4 in the sixth volume of this monograph series (Scheckenberger and Guther, 1998). This present chapter is intended both to demonstrate the practical execution of a design created in part though detailed modeling, and to act as a bridge between the pre-design modeling and postdesign modeling that supports a project such as this. A third chapter, after a three-year monitoring period, could return to a more modeling-based theme, outlining how the original models need to be revised with real post-construction data collected in the field.

Considerable stakeholder consultation and Agency permits have accompanied the final design stage of this project, which ran approximately eighteen months from assignment to construction start-up. The fact that the proposed works are being constructed on somebody else's land has increased the complexity of the project. To complicate matters further, the works, which are being constructed on a golf course, have required two concurrent contracts: one for the stormwater management and creek works, and another for the required golf course redesign. The final stage of the process will involve compliance monitoring of the solution, in accordance with legislative requirements. The monitoring phase will provide data to validate the system performance with computed performance using continuous simulation hydrologic modeling.

Bishop, B. and R.B. Scheckenberger. 2003. "Continuous Modeling for Design,Construction and Monitoring: A Case Study." Journal of Water Management Modeling R215-03. doi:

10.14796/JWMM.R215-03.

(C) CHI 2003 www.chijournal.org ISSN: 2292-6062 (Formerly in Practical Modeling of Urban Water Systems. ISBN: 0-9683681-7-4) 


\subsection{Introduction}

The purpose of this chapter is to explore, by way of a case study, the fundamental connection between theoretical modeling and practical design, construction, and monitoring of an engineered solution to a problem.

This study is of the management of potential stormwater impacts from new development on an existing stream system. The treatment of these common impacts has been achieved in an uncommon manner: the stormwater management works have been located off-site, approximately $400 \mathrm{~m}$ downstream of the residential development. Hydrologic and hydraulic modeling of the watercourse and floodplain has supported both the development of the solution, and the detailed engineering design of the stormwater management works. The models will be further applied in the required three-year compliance monitoring program.

\subsection{Background}

The theory, background, model development, and problem-solving process were presented at the Stormwater and Water Quality Management Modeling Conference in 1997 (Scheckenberger and Guther, 1998). The development area consists of 22.9 ha (56.6 acres) of low-density residential lands.

Urbanization generally reduces opportunities for stormwater to infiltrate, by increasing the impervious fraction of the drainage area, and also by grading and compacting some portions of the pervious fraction. This increases the volume and rate of stormwater runoff resulting in higher, more frequent peak flow rates from the developed area, leading to increased occurrences of flooding and erosion. Of particular importance to the Montgomery Creek study are the watercourse reaches located below the Niagara Escarpment, downstream of the development area, currently experiencing significant erosion within the golf course.

Through the Ontario Class Environmental Assessment (Class EA) process, the preferred solution was developed to include: an offline stormwater quality control wetland, an offline stormwater quantity and erosion control wet pond, and approximately $1500 \mathrm{~m}$ of natural channel rehabilitation and realignment works.

This chapter elaborates the second stage of the process: the design and construction of the proposed works. 


\subsection{Model Development through the Class Environmental Assessment}

\subsubsection{Montgomery Creek Class Environmental Assessment}

The Preferred Solution was developed through a two-year Class EA process. The solution, a combination of flood and water quality storage and watercourse improvements, addressed stormwater impacts from new development on the quantity and quality of runoff.

The purpose of the Class EA process is to promote the protection and conservation of the environment through comprehensive planning and informed decision-making. It allows evaluation of the environmental impacts of a project or alternatives to a project, as well as the assessment of the impacts of alternative methods of carrying out a project.

The primary purpose of this Class EA study was to determine the preferred stormwater management approach for developments located in the headwater of the Montgomery Creek (Development Area). The study focused on:

- determining the requirements for mitigation of flooding, erosion and water quality impacts of future development, and,

- where facilities are required, provision of stormwater management in a more efficient, co-ordinated manner for the entire development area through centralization of such facilities

The first step in the Class EA process is to provide a comprehensive description of the existing natural, social, economic cultural and technical environs found in the project study area. This baseline inventory provides a summary of key components to understand the potential impacts of land development and associated stormwater management.

The second step in the process involves screeningthe long list of various stormwater management techniques, which may, alone or in combination, reasonably address the potential flooding, erosion and stormwater quality impacts. The third step is the detailed evaluation of the screened short list of management alternatives, using such factors as: economics, compatibility with future development, compatibility with the natural environment, and social impacts. Detailed modeling of each of the alternatives is carried out in this step.

The fourth step is the selection of a Preferred Solution, and presentation of the solution to the agencies and the public. Since no further review was requested, the City proceeded to final design of the Preferred Solution. 


\subsubsection{Flow and Erosion Assessment}

\section{Model Description}

To determine existing and future runoff for assessing the impact of proposed urban development on the Montgomery Creek tributary, a hydrologic simulation technique was adopted for system evaluation and design. Continuous simulation, using historical rainfall data as input to generate a long term timeseries of flows at various key points in the watershed, provided the information base to associate a peak flow with frequency. In addition continuous simulation facilitated the evaluation of water quality and quantity management strategies through the full range of flow conditions, from baseflow to flood flows.

The Hydrologic Simulation Program - Fortran (HSP-F), developed by HydroComp Inc. for the US-EPA, was selected since it is a provincially approved technique. The HSP-F model used in this analysis was based on a calibrated model of the Red Hill Creek developed in 1989 (Philips Planning and Engineering, 1989) modified and discretized to the level of detail required for this study. Precipitation, evaporation, and snowmelt processes were simulated in the updated HSP-F model, in order to assess the seasonal performance of stormwater management alternatives over a full year.

\section{Watercourse Description}

The reaches below the Niagara Escarpment, downstream of the proposed Development Area experience significant erosion. It is considered that any additional urban development without proper stormwater management may increase erosion potential on the downstream watercourses with possible damage to downstream properties.

In a typical natural watercourse, the long term stream form (morphology) is primarily influenced by bank-full flow conditions which may occur annually in natural watersheds (OMNR, 1994). In urbanized watersheds, until the channel reaches a new dynamic equilibrium configuration, the bank-full flow events occur more frequently, which, in conjunction with man-made alterations to stream geometry, or the relationship of the stream to flood plain, increase erosion potential.

The watercourse immediately downstream of the $2700 \mathrm{~mm}$ diameter storm outfall to the toe of the escarpment, is typically resistant to erosion despite changes in flow regime. This characteristic is based on its substrate and type, verified through field reconnaissance. 


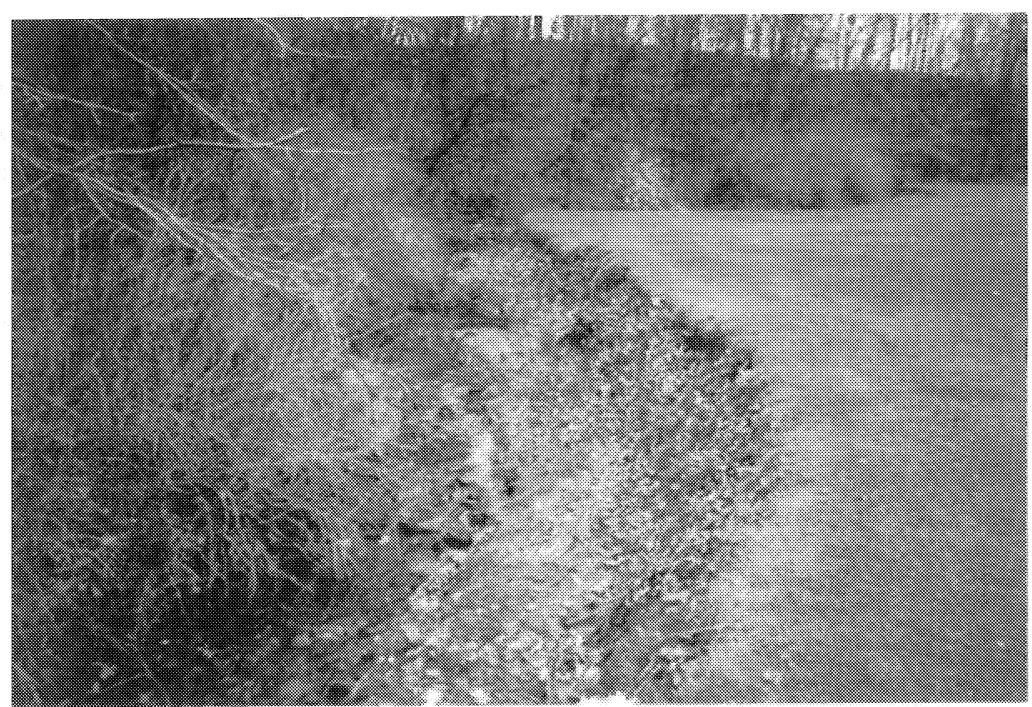

Figure 3.1 Pre-existing creek with typical ongoing erosion.

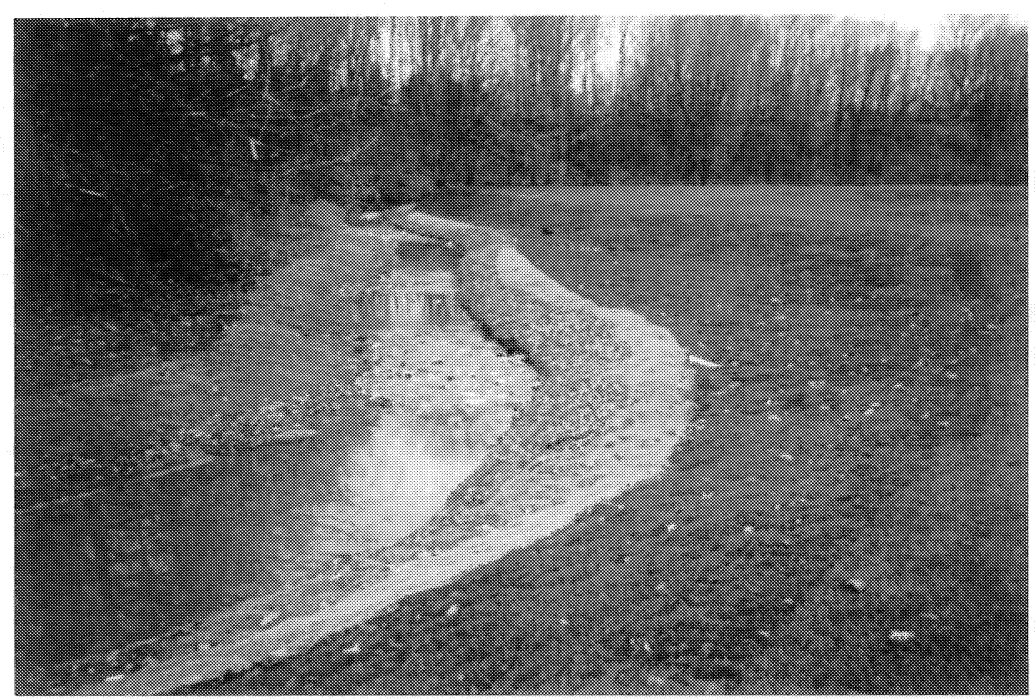

Figure 3.2 Realigned creek, sodded, with temporary (winter) erosion control mat. 
The channel in this location exhibits steep channel slopes of approximately $6 \%$, with substrate consisting of large angular limestone cobbles progressing to boulders and bedrock approaching the Niagara Escarpment Crest. This section of the watercourse also exhibits stepped pool sequences with a small meander amplitude (i.e. sinuosity $=1.1$ ). Based on the Rosgen classification system this section of the watercourse can be categorized as a Type A stream. This type of stream is inherently stable and resists erosion when subjected to changes in flow regime (Rosgen 1994, Annable 1994). Based on the foregoing, the stream morphology of the upper reach of the Montgomery Creek, as it traverses the escarpment (i.e. to the upstream limit of the golf course) would not be expected to experience a significant change in erosion rate or morphology, due to the proposed upstream development.

The watercourse through the golf course however exhibits a number of active erosion sites. The bank soils are primarily sandy loam with low cohesion underlain by cohesive clay. The cross-sectional geometry is also typically characterized by steep-sided slopes which leave the stream bank vulnerable to erosion even during low to moderate runoff events.

\section{Results (Flow)}

The continuous time series was analyzed using the three-parameter log normal distribution, where the co-efficient of skew is positive. The 2-y through 100-y return period flows were generated. The results indicated that full development without mitigation would result in maximum increases in peak flows of 39\% from a $2700 \mathrm{~mm}$ diameter storm outfall at the lower end of the development area during a 2-y event. This increase would largely be due to the increased drainage area to the storm sewer system, due to a redistribution of flow from the local watercourses to the storm sewer system. The net increase in the 2-y peak flow would be $7.5 \%$ reflected at the toe of the Niagara Escarpment (i.e. confluence of the storm sewer outfall and Montgomery Creek).

The maximum increase in peak flow at the downstream limit within the golf course would be approximately $13 \%$ for a 2 -y storm event. Under more severe storm events (i.e. less frequent), the peak flows would increase marginally or even decrease.

\section{Results (Erosion)}

An assessment of the existing watercourse's susceptibility to erosion, in relation to proposed development and stormwater management techniques, was undertaken as part of the Class EA using a duration analysis approach, and 
the continuous simulation HSP-F model. Duration analysis is based on the principle of determining the length of time a watercourse is exposed to erosive flow rates. Typically a watercourse is stable under low flow and extreme flood flows when spill of flow into the floodplain causes backwater effects that partially relieve shear stress; it is the flow rates associated with frequent storm events which most often are cited as erosive.

As indicated, the watercourse downstream of the proposed developments exhibits numerous erosion zones, which typically feature near vertical side slopes and exposed soils (i.e. typically erodible sandy loam). This existing unstable condition means that any storm event would cause some erosion. Based on these site conditions, and cross-sectional geometry, the erosion assessment has conservatively included the evaluation of shear force (i.e. erosive force) resulting from all flows in excess of $0.1 \mathrm{~m}^{3} / \mathrm{s}$. This flow corresponds to the threshold velocity and critical shear stress for the ambient soil particles. This approach ensures that all erosive rainfall/runoff events are included in the assessment. The sum of the cumulative shear (i.e. long term summation of shear stress multiplied by time), which occurs at various channel cross-section locations, was used as an index or measure to compute the effectiveness of the various stormwater management alternatives considered in this assessment.

Cumulative shear force was summarized at various locations, and at various depths at each location, along Montgomery Creek, for existing and future land use for a three year period, corresponding to wet, dry and average rainfall years. The HSP-F duration analysis uses the results of the continuous hydrologic simulation to determine the cumulative shear forces exerted on the channel banks. This allows calculation of changes in erosion potential, by developing a quantitative index of erosion potential. This index can then be used to assess the impacts of various land use changes and of alternative stormwater management techniques.

Table 3.1 summarises cumulative shear force at various locations along Montgomery Creek. The summary is based on existing and future land use (i.e. development area) for a three year period, corresponding to wet, dry and average rainfall years.

The results indicate that uncontrolled development would increase erosion potential in the downstream watercourse (through the golf course) by a maximum of $9.49 \%$ in a typical stream cross section. 
Table 3.1 Cumulative shear force.

Existing and future land-use (no stormwater management).

\begin{tabular}{|c|c|c|c|c|c|}
\hline \multirow[t]{2}{*}{ Land Use } & \multicolumn{5}{|c|}{ Cumulative Shear at Stations $\left(\mathrm{Pa}^{*} 15 \mathrm{~min}\right)$} \\
\hline & $\begin{array}{c}\text { Toe of Bank } \\
\text { (0x Bankfull } \\
\text { Depth) }\end{array}$ & $\begin{array}{c}20 \% \text { of } \\
\text { Bankfull } \\
\text { Depth }\end{array}$ & $\begin{array}{c}50 \% \text { of } \\
\text { Bankfull } \\
\text { Depth }\end{array}$ & $\begin{array}{c}80 \% \text { of } \\
\text { Bankfull } \\
\text { Depth }\end{array}$ & $\begin{array}{c}100 \% \text { of } \\
\text { Bankfull } \\
\text { Depth }\end{array}$ \\
\hline Existing & 193161 & 114708 & 8967 & 4081 & 2224 \\
\hline $\begin{array}{l}\text { Future } \\
\text { (No Stormwater } \\
\text { Management) }\end{array}$ & 193263 & 116879 & 9817 & 4328 & 2349 \\
\hline$\%$ Change & 0.05 & 1.89 & 9.49 & 6.06 & 5.62 \\
\hline
\end{tabular}

\subsubsection{Summary of the Preferred Solution}

Various alternative stormwater management strategies mitigating the negative effects of pollutant loadings and erosion potential were evaluated, using agencyapproved modeling and evaluation techniques. The pollutant removal performance of each stormwater management technique was assessed based on (i) Ontario Ministry of the Environment (MOE) criteria for storage volumes for end-of-pipe facilities, and (ii) mass loading of pollutants using an event mean concentration methodology in conjunction with continuous simulation which indicated the fraction of the total stream flow treated in the off-line system.

For erosion, end-of-pipe storage was assessed under a number of reasonable alternative configurations, using the cumulative shear stress indices. No alternative forms of erosion modeling have been used in this project. The percentage change in cumulative shear at various bed and bank stations was calculated compared to existing conditions, as shown in Table 3.2.

The analysis demonstrates the following:

- the effectiveness of the End-of-Pipe BMP above the escarpment is primarily related to the release rate from the facility and performance is improved with consideration of infiltration losses from the facility.

- End-of-Pipe facilities utilizing $24 \mathrm{~h}$ drawdown and $38 \mathrm{~mm} / \mathrm{ha}$ storage were effective in mitigating increased erosion at higher bank stations (i.e during near bankfull flow)

- standard extended detention storage and drawdown periods do not effectively mitigate increased erosion potential in low bank stations (i.e toe of slope region). 
Table 3.2 Cumulative shear force.

Existing and future land-use with End-of-Pipe treatment.

\begin{tabular}{|c|c|c|c|c|c|c|}
\hline \multirow[t]{2}{*}{$\begin{array}{l}\text { Facility } \\
\text { Location }\end{array}$} & \multirow[t]{2}{*}{$\begin{array}{l}\text { Stormwater Management } \\
\text { Alternative }\end{array}$} & \multicolumn{5}{|c|}{$\begin{array}{l}\text { \% Change in Cumulative Shear at Various Bed and } \\
\text { Bank Stations as compared to Existing Conditions }\end{array}$} \\
\hline & & $\begin{array}{l}\text { Toe of } \\
\text { Bank }\end{array}$ & $\begin{array}{c}0.2 \\
\text { Depth }\end{array}$ & $\begin{array}{c}0.5 \\
\text { Depth }\end{array}$ & $\begin{array}{c}0.8 \\
\text { Depth }\end{array}$ & $\begin{array}{c}1.0 \\
\text { Depth }\end{array}$ \\
\hline On-Site & $\begin{array}{l}\text { Future Land Use with } \\
\text { End-of-Pipe Facility in } \\
\text { the Development Area } \\
\left(3500 \mathrm{~m}^{3} \text { storage, } 24 \mathrm{~h}\right. \\
\text { drawdown and } 1-3 \mathrm{~L} / \mathrm{s} \\
\text { infiltration losses from } \\
\text { facility) }\end{array}$ & 0.06 & -0.5 & 0.14 & -1.59 & -2.39 \\
\hline On-Site & $\begin{array}{l}\text { Future Land Use with } \\
\text { End-of-Pipe Facility in } \\
\text { Development Area ( } 3150 \\
\mathrm{~m}^{3} \text { storage, } 24 \mathrm{~h} \\
\text { drawdown and no } \\
\text { infiltration losses from } \\
\text { facility) }\end{array}$ & 2.28 & 3.12 & 0.07 & -1.31 & -2.31 \\
\hline On-Site & $\begin{array}{l}\text { Future Land Use with } \\
\text { End-of-Pipe Facility in } \\
\text { Development Area [3150 } \\
\mathrm{m}^{3} \text { storage, } 168 \mathrm{~h}(7 \mathrm{~d}) \\
\text { drawdown and no } \\
\text { infiltration losses from } \\
\text { facility] }\end{array}$ & 1.49 & 0.94 & 1.45 & 0.65 & -0.21 \\
\hline Off-Site & $\begin{array}{l}\text { Future Land Use with } \\
\text { End-of-Pipe Facility on } \\
\text { Golf Club Lands ( } 3500 \\
\mathrm{~m}^{3} \text { storage in quality and } \\
\text { quantity facility) }\end{array}$ & 1.46 & 4.3 & 5.05 & -4.90 & -5.89 \\
\hline Off-Site & $\begin{array}{l}\text { Future Land Use with } \\
\text { End-of-Pipe Facility on } \\
\text { Golf Club Lands ( } 2800 \\
\mathrm{~m}^{3} \text { storage in quality and } \\
\text { quantity facility) }\end{array}$ & 0.97 & 3.48 & 5.27 & -3.99 & -4.00 \\
\hline Off-Site & $\begin{array}{l}\text { Future Land Use with } \\
\text { End-of-Pipe Facility on } \\
\text { Golf Club Lands ( } 2300 \\
\mathrm{~m}^{3} \text { storage in quality and } \\
\text { quantity facility) }\end{array}$ & -1.27 & 0.52 & 7.23 & 2.39 & 2.69 \\
\hline $\mathrm{N} / \mathrm{A}$ & $\begin{array}{l}\text { Future Land Use - No } \\
\text { Stormwater Management }\end{array}$ & 0.05 & 1.89 & 9.49 & 6.06 & 5.62 \\
\hline
\end{tabular}


- seepage loss from the stormwater storage system, which essentially loses flow from the system would effectively mitigate increased erosion potential at all channel bank stations.

- an off-site facility would provide effective mitigation of upper bank station (i.e. top of channel bank) erosion impacts, however large volumes of storage would be required to control erosion impacts on lower bank stations (i.e. toe of channel bed/bank)

- stabilization of the toe region of the downstream watercourse merits attention as a supplemental erosion mitigation technique to storage

The off-site alternative (downstream of the development in the golf course) would remove $53 \%$ more sediment from the watercourse than the onsite alternative (in the development, receiving only urban runoff). The off-site alternative, located off-line on the Montgomery Creek would intercept and remove a greater volume of pollutants than the on-site alternative. It would therefore be considered to provide superior water quality performance in the context of the downstream sections of the Montgomery Creek. The off-site alternative would, however, likely result in incremental increases in sediment and other pollutants associated with urban land use from the $2700 \mathrm{~mm}$ diameter outfall downstream of the proposed facility (since no at-source treatment would be advanced). Downstream of the facility, water quality would be expected to improve over existing conditions due to the complete capture of frequent first flush runoff events with their high pollutant concentrations. Consideration was given to (i) the development area constitutes less than $20 \%$ of the development discharging to the storm sewer at the top of the escarpment, and (ii) the creek section downstream of the sewer outfall to the golf course is very steep and inaccessible to fisheries. Given the overall environmental improvement to the watercourse/watershed, the foregoing impact was considered to be a reasonable trade-off of the off-site solution.

In summary, the Preferred Solution would result in:

- the lowest construction cost,

- the lowest land cost,

- the lowest routine maintenance cost,

- no grading constraints to the development area,

- reuse of existing storm infrastructure,

- the greatest improvement to stormwater quality downstream of the golf course,

- an improved golf course aesthetically, with lower annual creek erosion repair costs, and 


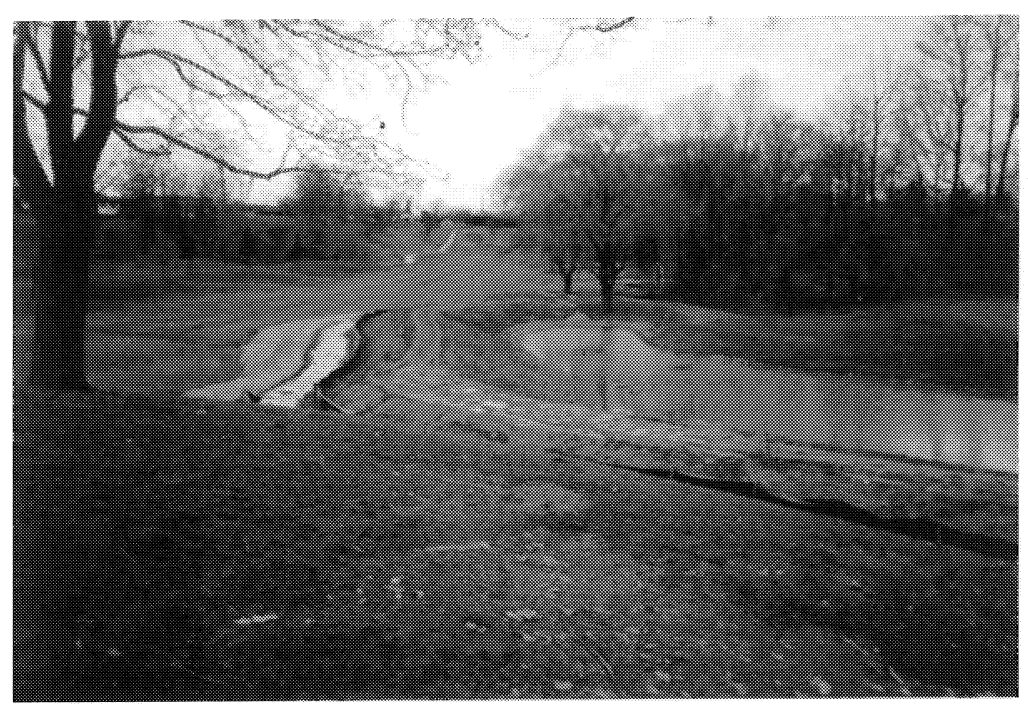

Figure 3.3 Stormwater quality facility.

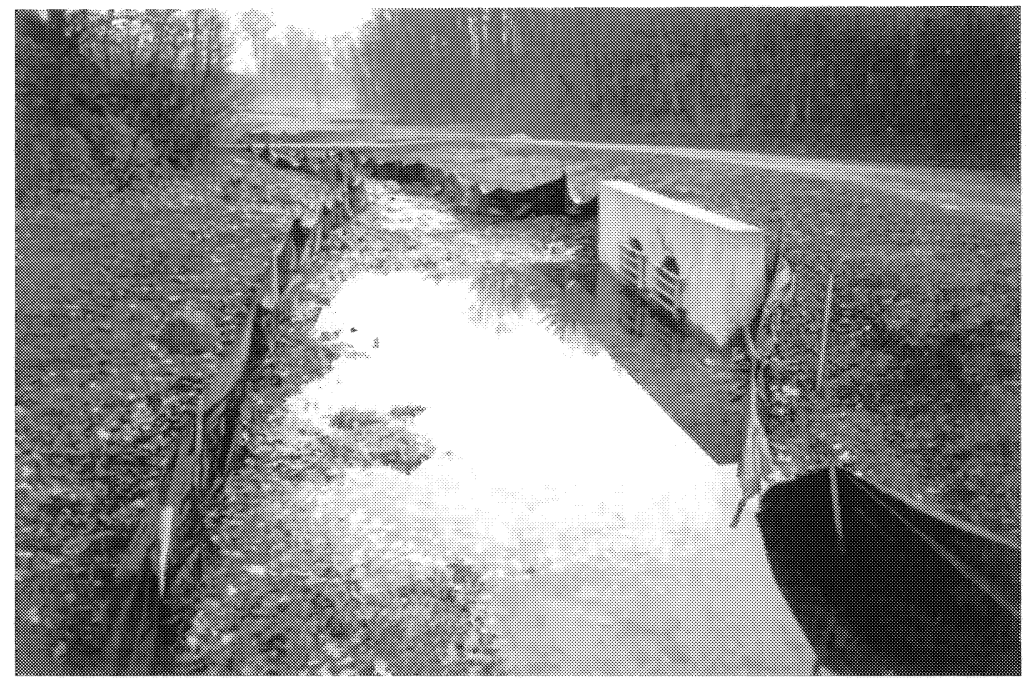

Figure 3.4 Flow splitter inlet to stormwater quantity and erosion control facility. 
- less disruption to existing roads to construct duplicate infrastructure.

\subsection{Design, Approvals, and Construction Process}

\subsubsection{Design and Construction Process}

Once the City authorized the final design of the preferred solution, described in the Class EA, a team of specialists was assembled to support the water resources engineers. The design team comprised the following disciplines: water resources engineering, fluvial geomorphology, terrestrial biology/landscape architecture, aquatic biology, and geotechnical engineering. Two of the four subconsultants (terrestrial biology/landscape architecture and aquatic biology) were previously involved in the Class EA process.

The design team produced a coordinated preliminary design for the creek rehabilitation and the two stormwater management facilities (i.e. quality management wetland and quantity management wetpond). Additional input was solicited from the golf course operators and from the golf course architect who was working on a concurrent design for the new golf features, described later in this chapter.

Once a consensus on the final design was reached with the City and the golf course, the contract packages were assembled. Tendering and award of the contracts occurred in August 2001, with a construction start date of October 1, 2001 to minimize the impact on play.

Staging of the works was an important element of the construction process, whereby the fill material for two new greens was to be provided by the creek contractor to the golf contractor as the first priority. Once this operation was completed, the balance of the excavation work could proceed.

The construction of most of the stormwater management facilities and creek works was completed in October and November 2001. The project was shut down for the winter by the second week in December. The creek contractor returned for two weeks on March to complete the creek works in frozen conditions, prior to the coldwater fisheries habitat restriction window that commenced March 31, 2002. Daily construction supervision was provided, with site visits by the geomorphologist as required.

An aspect of every construction job is the potential for field adjustments to the design. The most significant change in this project was in the disposition of the fill material, which was directed by the golf course architect. Any excess 
fill was placed in a disposal embankment, up out of the valley and floodplain to minimize hydraulic impacts. A section of the creek pool-riffle sequence was altered in the field to enhance the performance of the quantity management facility intake structure. This particular change will need to be fully documented and recoded into the hydraulic model for the project, to verify the long-term performance of the facility and creek.

The final step in the construction process is the preparation of an as-built survey. This information will be retained by the City for a legal record of its infrastructure, as the legal owner/operator of the stormwater management facilities. It will also be submitted to the Agencies as a condition of the compliance monitoring.

\subsubsection{Details of the Design Exercise}

The design and construction of the two stormwater management facilities (a water quality control wetland and an erosion control wet pond) and approximately $1500 \mathrm{~m}$ of natural channel works, must first be technically supported by the models. The continuous simulation hydrologic model (HSP-F), and hydraulic model (HEC-RAS) used in the preliminary design phase were refined as part of detailed design. An additional geodetic survey was completed by City forces throughout the project limits. New cross-sections were added to the hydraulic model. The characteristics of the existing creek and valley were remodeled, in order to provide input to the detailed design of the stormwater management facilities. The model results were also provided to the fluvial geomorphologist to commence the detailed design of the creek works.

Continuous simulation modeling was used for: duration analysis (erosion), equivalent removal analysis (quality), frequency analysis (design flows for channel design), and baseflow and bankfull estimates.

The hydraulic model was used for the facility embankment design and for the floodline impact assessment as part of the cut/fill permitting. This analysis demonstrated, through a comparison of pre- and post-construction floodplain volumes and depths, that there would be no loss of floodplain storage throughout the site, nor any increase in off-site flood levels as a result of the project.

As noted, the stormwater management and creek contract and golf contracts were concurrent, yet often had differing objectives. Design information (grades, plan and profiles) for the stormwater management facilities, creek work, and associated features was provided to the golf course architect in order to make the two contracts as seamless as possible. The new greens, fairways, 


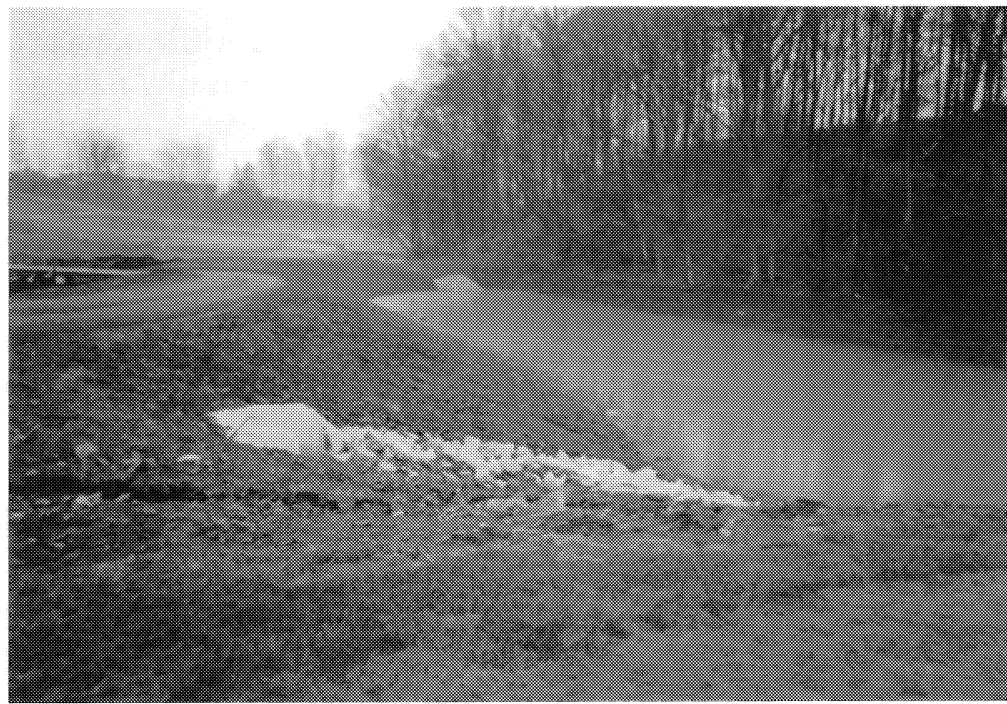

Figure 3.5 Stormwater quantity and erosion control facility.

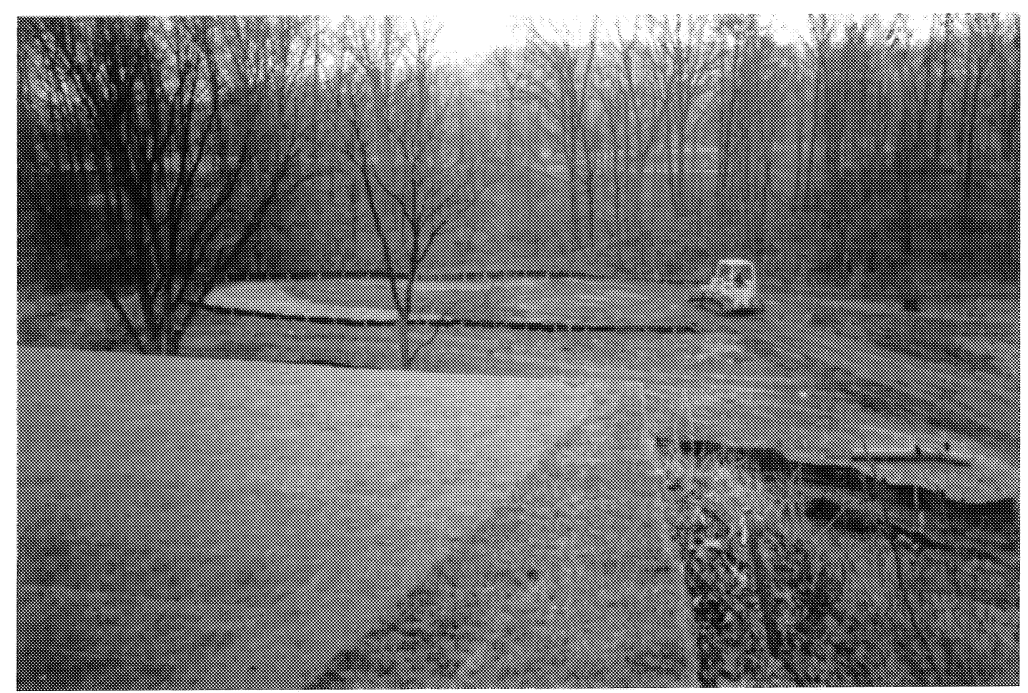

Figure 3.6 Construction of new green in valley adjacent to creek. 
and tees were designed to function with the creek contract elements. The new greens were designed in the floodplain, in the vicinity of existing greens. The governing principle for the works was that the project was to result in no net loss in floodplain storage.

The detailed geomorphic design, in conjunction with the two stormwater management facilities and golf course details, created the need for timely information transfer. One constant underlying factor for the two contracts was the timing of the work. The golf course would not close sooner than October 1,2001 and was to reopen May 1, 2002. All in-stream work was to be completed prior to March 31, 2002, on account of the coldwater fisheries habitat downstream. Asphalt, sod and plant material would not be available prior to midApril. Finally, the possible severity of the winter season could hamper progress.

One particular aspect of the design that required the use of the hydraulic model was the design of the two flow splitters, one at each of the two stormwater management facility inlets. To split the flow in accordance with the design, the invert elevations of the inlet pipes were designed and constructed at a specific in-stream frequency flow and depth, which was calculated with the hydrologic and hydraulic models, and then verified in the field through survey of the relevant cross-sections, creek inverts, and pipe inverts. The stormwater quality facility inflow structure is designed to intercept flow in the creek resulting from a $13 \mathrm{~mm}$ rainfall event and greater. The stormwater erosion control facility inflow structure is designed to intercept flow in the creek resulting from a $25 \mathrm{~mm}$ rainfall event and greater. The inlet configurations were enhanced with the creation of a riffle immediately downstream of the intake

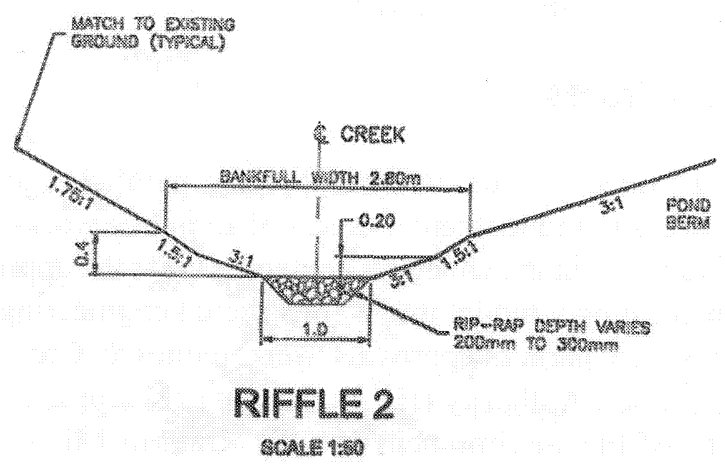

Figure 3.7 Typical riffle design section. 


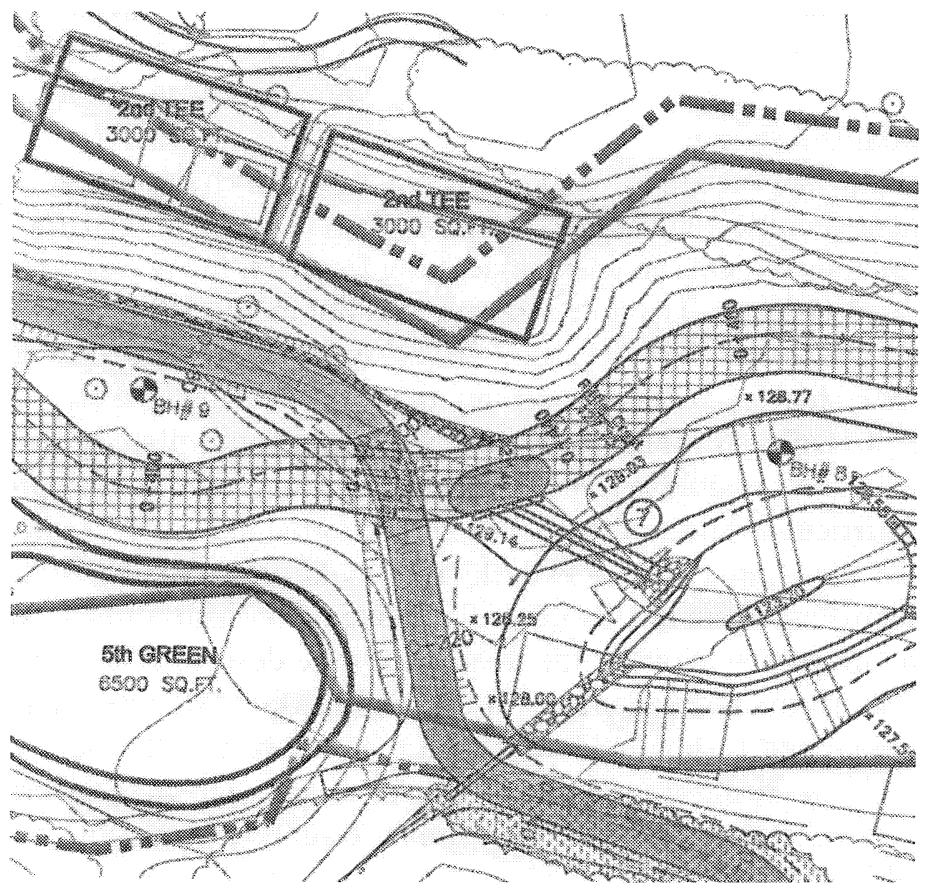

Figure 3.8 Excerpt from project plan drawings showing facility inlet.

structure (i.e. a pool at the intake, with a stable, predictable water surface elevation). This design was coordinated with the fluvial geomorphologist, and has proven successful in the field to date.

\subsubsection{Approvals Process}

Any engineering project of this nature requires a parallel Agency approval process. This process is a fundamental aspect of all public works. The purpose of including this section in the chapter is to demonstrate the approvals process involved in transforming a model into a constructed engineering project.

A total of seven permits/approvals were required: City of Hamilton, Hamilton Conservation Authority (HCA), Niagara Escarpment Commission, Ontario Ministry of the Environment (MOE), Ontario Ministry of Natural Resources (MNR), Canada Department of Fisheries and Oceans (DFO), and Environment Canada. 


\subsubsection{Details of the Approvals}

The final design drawings, together with a detailed design brief, were submitted with all of the Agency applications in the first week of January 2001. The approvals were largely in place by September 2001. The approvals submission package relied on information derived from the continuous simulation hydrologic model as technical support for the HCA Fill Permit, DFO Authorization, and MOE Certificate of Authorization. The hydraulic model was also used as input to the package to secure the MNR Lakes and Rivers Work Permit, and the HCA Fill Permit.

As a result of the DFO six-month preliminary screening, the DFO requested that a Cumulative Environmental Effects Assessment be done for the application, and a detailed monitoring program be submitted for their review. The two-year post-construction monitoring program, to be completed by the City, will involve further modeling of the facilities, and annual inspections of the creek and stormwater management works for erosion, terrestrial and aquatic biology.

From the time the City chose to proceed to Final Design (February 2000) to Spring 2002 there have been 30 meetings: six set-up and cost-sharing meetings with City, twelve design meetings with golf course and City, four preconstruction meetings with the contractors, and eight site meetings.

\subsection{Overview of the Constructed Works}

\subsubsection{Creek and Stormwater Management Works}

The creek rehabilitation/realignment and stormwater management works involved the construction of:

- an $1850 \mathrm{~m}^{3}$ extended detention wetland for stormwater quality control

- a $1200 \mathrm{~m}^{3}$ extended detention wet pond for stormwater quantity and erosion control

- $819 \mathrm{~m}$ of complete channel realignment and redesign

- $1149 \mathrm{~m}$ of bank regrading and stabilization

- an access road for maintenance, including a new bridge

- $10450 \mathrm{~m}^{3}$ of earth excavation (all items) 


\subsubsection{Golf Course Works}

The golf works involved the creation of:

- two new greens and fairways,

- four new tee blocks,

- realignment of a $100 \mathrm{~m}$ portion of one fairway,

- $500 \mathrm{~m}$ of new cart paths,

- new irrigation for the two new holes, and

- repairs to existing irrigation along the length of the creek/ stormwater management works.

\subsection{Next Steps}

Once the works are completed in the Spring (2002), the final stage of the process will be initiated, involving monitoring of the solution (a three-year program, which was a condition of the DFO authorization).

The monitoring phase will provide data to validate the system performance with computed performance using continuous simulation hydrologic modeling (in addition to the assessment of fisheries habitat, watercourse stability, erosion control and plantings).

The proposed construction monitoring plan for the 2001/2002 construction year has been established based on DFO's requirements for the pre-, during-, and post-construction monitoring tasks as outlined in the following: Pre-construction Tasks:

1. Co-ordinate startup construction coordination meeting, between all interest parties and approval agencies.

2. Document existing channel conditions, with respect to channel form, function, vegetative cover and fish habitat.

During Construction Tasks:

1. Document channel realignment construction through photographs according to DFO's outline.

2. Monitor channel staging operations.

3. Provide on-site construction supervision.

4. Channel realignment fluvial geomorphologist supervision. Post-Construction Tasks:

1. Document post-construction channel conditions through photographs.

2. "As constructed" drawings. 
3. Fluvial geomorphic assessment of "as constructed" conditions.

4. Fisheries habitat assessment of "as constructed" conditions.

5. Mitigative vegetative planting plan results assessment.

6. Post-construction monitoring report.

Years 2003 - 2004 Monitoring Plan

The proposed annual monitoring tasks have been established for the years 2002-2004 based on DFO's requirement for a short-term post-construction monitoring plan as follows:

1. Fluvial geomorphic assessment of springtime channel conditions.

2. Fisheries habitat assessment of springtime channel conditions.

3. Channel vegetative planting plan condition assessment.

4. Annual monitoring report.

\subsection{Conclusion}

Considerable stakeholder consultation (in the form of a Class EA, pre-design meetings and detailed design meetings) and Agency permits have accompanied the final design stage of this project, which ran approximately eighteen months from assignment to construction start-up.

The models developed at the outset of the project (during the Class EA) continue to be used for preliminary and final design, agency approvals, in-field design changes, and ultimately for compliance monitoring.

\section{Acknowledgments}

The authors wish to acknowledge the following: City of Hamilton; Glendale Golf and Country Club; Hamilton Conservation Authority; Development Community; Parish Geomorphic; Dougan and Associates; C. Portt and Associates; Terraprobe Limited; Carrick Design; and R \& M Construction.

\section{References}

Annable, W. K., 1994, Morphological Relationships of Rural Watercourses in Southwestern Ontario and Selected Field Method in Fluvial Geomorphology, Ontario Ministry of Natural Resources, ISBN 0-77-78-2669-2 
Bicknell, B.R., Imhoff, J. C., Kittle J. L. and A.S. Donigian, 1993. Hydrological Simulation Program - Fortran (HSP-F) User's Manual for Release 10. U.S. EPA, EPA-6-R93-174

Marshall Macklin Monaghan Limited, 1994. Stormwater Management Practices Planning and Design Manual, Report prepared for the Environmental Sciences and Standards Division - Program Development Branch, Ontario Ministry of Environment and Energy, ISBN 0-7778-2957-6

Municipal Engineers Association, 2000, Municipal Class Environmental Assessment

Ontario Ministry of Environment, 1999. Draft Update - Stormwater Management Practices Planning and Design Manual

Ontario Ministry of Natural Resources, 1994. Natural Channel Systems. An Approach to Management and Design, Queen's Printer for Ontario

Parish Geomorphic, 2000. Montgomery Creek Bank Stabilization and Realignment, Geomorphological Investigation and Recommendations, Report to Philips Engineering Ltd.

Philips Engineering Ltd., 2000. Montgomery Creek - Glendale Alternative Watercourse Stabilization and Stormwater Management, Final Design Technical Brief, Report to Regional Municipality of Hamilton-Wentworth

Philips Planning and Engineering Limited, 1989. Mountain East-West and NorthSouth Transportation Corridor Drainage Study, 1989, Report to Regional Municipality of Hamilton-Wentworth Freeway Project Office

Philips Planning and Engineering Limited, 1997. Montgomery Creek Stormwater Management Class Environmental Assessment, Report to Regional Municipality of Hamilton-Wentworth

Rosgen, 1994, Classification of Natural Rivers, Catena, Vol. 22: 169-199 Elsevier Science, B.V. Amsterdam

Scheckenberger, R.B. and R.T. Guther. 1998. "Stormwater Management on Somebody Else's Land!" Journal of Water Management Modeling R200-04. doi: 10.14796/JWMM.R200-04.

Terraprobe Limited, 2000. Geotechnical Investigation, Proposed Channel Improvements, Montgomery Creek, Hamilton Ontario, Report to Philips Engineering Ltd.

Urban Drainage and Flood Control District, Denver, Colorado, 1999, Urban Storm Drainage Criteria Manual: Volume 3 - Best Management Practices. 